\title{
O financiamento da educação de jovens e adultos em municípios mineiros no período de 1996 a 2006:
} até quando migalhas?

\author{
GERUZA CRISTINA MEIRELLES VOLPE \\ Universidade Federal de Juiz de Fora
}

\section{INTRODUÇÃO}

O ordenamento constitucional-legal brasileiro conquistado no final da década de 1980 definiu as bases do Estado democrático e instituiu um "novo pacto federativo”. A Constituição Federal de 1988 garantiu aos municípios o estatuto de ente federado, antes exclusivo dos estados e da União. Assim, eles tornaram-se “componentes da arquitetura da federação". Na prática, os municípios passaram a ter maior autonomia, devendo elaborar suas leis orgânicas, instituir e arrecadar tributos próprios, eleger seus prefeitos e vereadores, criar seus sistemas de ensino e organizá-los em regime de colaboração com os sistemas federal e estadual (Farenzena, 2006, p. 50).

De uma perspectiva tributária, a ênfase no fortalecimento da federação ocorreu mediante elevação da participação dos estados e municípios no conjunto da receita. Descentralização acompanhada por mecanismos redistributivos aumentando a base de tributação dos governos subnacionais e incrementando sua participação nos recursos federais (Brasil, 2007, p. 1). Na verdade, os municípios foram os maiores beneficiários do processo de descentralização tributária - ver estudos do Banco Nacional de Desenvolvimento Econômico e Social (BNDES) realizados 
por Afonso et al. (1998a, 1998b), respectivamente, sobre o crescimento da receita tributária e da despesa municipal.

Nesse novo contexto, a ampliação do atendimento educacional que se fazia, sobretudo pela matrícula em redes estaduais até a década de 1990, viu crescer a participação das redes municipais com um incremento significativo, principalmente em virtude das mudanças na política de financiamento da educação no país. Logo, a intensa municipalização da matrícula do ensino fundamental brasileiro, destacadamente impulsionada pela criação do Fundo de Manutenção e Desenvolvimento do Ensino Fundamental e de Valorização do Magistério (FUNDEF), embora não fosse inédita no cenário brasileiro, definiu de forma intensa o espaço municipal como local de gestão e financiamento da política educacional.

No que se refere especificamente à educação de jovens e adultos (EJA), com base nos dados disponibilizados pelo Edudatabrasil do Instituto Nacional de Estudos e Pesquisas Educacionais Anísio Teixeira (INEP), construímos uma série histórica, de 2000 a 2006, mostrando a evolução da matrícula dessa modalidade, segundo a unidade administrativa. Se a evolução percentual do crescimento das matrículas foi de aproximadamente $42,5 \%$ no total, não se pode desconsiderar que as esferas responderam muito diferentemente a esse incremento: nos municípios esse crescimento foi de cerca de $111,5 \%$ contra apenas $26,5 \%$ da rede estadual. Em números absolutos, é mister observar que as redes municipal e estadual aproximaram-se consideravelmente a partir de 2002.

\section{Tabela 1 - Brasil: Evolução das matrículas em EJA por dependência administrativa - 2000 a 2006}

\begin{tabular}{c|r|c|c|c|c|c|c|c|c|c}
\hline $\begin{array}{c}\text { Dep. } \\
\text { Adm.l } \\
\text { Ano }\end{array}$ & \multicolumn{2}{|c|}{ Federal } & \multicolumn{2}{c|}{ Estadual } & \multicolumn{2}{c|}{ Municipal } & \multicolumn{2}{c|}{ Privada } & \multicolumn{2}{c}{ Total } \\
\cline { 2 - 12 } & $\mathbf{N}^{\mathbf{0}}$ & $\%$ & $\mathbf{N}^{\mathbf{0}}$ & $\%$ & $\mathbf{N}^{\mathbf{0}}$ & $\%$ & $\mathbf{N}^{\mathbf{0}}$ & $\%$ & $\mathbf{N}^{\mathbf{0}}$ & $\%$ \\
\hline 2000 & 11.573 & 0,34 & 2.018 .504 & 59,18 & 1.005 .218 & 29,47 & 375.535 & 11,01 & 3.410 .830 & 100 \\
\hline 2001 & 5.490 & 0,15 & 2.004 .321 & 53,05 & 1.416 .117 & 37,48 & 352.061 & 9,32 & 3.777 .989 & 100 \\
\hline 2002 & 3.327 & 0,09 & 1.759 .487 & 46,55 & 1.700 .862 & 45,00 & 315.917 & 8,36 & 3.779 .593 & 100 \\
\hline 2003 & 1.284 & 0,03 & 2.166 .915 & 29,21 & 1.953 .280 & 44,36 & 281.957 & 6,40 & 4.403 .436 & 100 \\
\hline 2004 & 697 & 0,02 & 2.305 .344 & 50,37 & 2.025 .617 & 44,25 & 245.610 & 5,37 & 4.577 .268 & 100 \\
\hline 2005 & 875 & 0,02 & 2.329 .966 & 50,44 & 2.070 .606 & 44,82 & 217.962 & 4,72 & 4.619 .409 & 100 \\
\hline 2006 & 1.203 & 0,02 & 2.553 .819 & 52,53 & 2.126 .552 & 43,74 & 179.816 & 3,70 & 4.861 .390 & 100 \\
\hline
\end{tabular}

$\mathrm{N}^{\mathrm{o}}=$ Número absoluto de matrículas na dependência administrativa; \% = Percentual da matrícula na dependência administrativa em relação ao total do ano.

Fonte: MEC/INEP. Elaborada pela autora com base em consulta a relatórios diversos do Edudatabrasil. Disponível em: $<$ http://www.edudatabrasil.inep.gov.br >. Acesso em: set. 2008.

Enfim, a considerável representatividade nas finanças públicas nacionais da arrecadação tributária a cargo das municipalidades, de gastos, recursos e, sobretudo, responsabilidades a elas transferidas (por exemplo: carreira de professores, estratégias de formação, condições de oferta), acrescida da municipalização verificada nas matrículas, justifica uma avaliação mais apurada do comportamento dos municípios brasileiros. 
Por todo o exposto, verificou-se a pertinência de se entender este ente da federação e as implicações do modelo de financiamento da educação para as possibilidades de realização da política educacional para jovens e adultos nessa esfera.

O presente texto compõe síntese de uma investigação em nível de doutorado, intitulada O financiamento da educação de jovens e adultos no período de 1996 a 2006: farelos de migalhas, defendida em fevereiro de 2010 no Programa de Pós-Graduação em Educação da Universidade Estadual de Campinas (UNICAMP), sob orientação da professora doutora Sonia Giubilei. A investigação teve como questão central: Constituiu o financiamento da educação de jovens e adultos um direito, no interregno 1996 a 2006? Como questões estruturais imbricaram-se imediatamente: Por que financiar a EJA? A quem se destina? Para quê? Quem a financiou? E como o fez? Para respondê-las, uma discussão teórica ampla e abrangente sobre os aspectos econômico-tributários, sociais e históricos do financiamento da educação (de jovens e adultos) culmina num estudo empírico do estado de Minas Gerais e de uma amostra de 24 municípios mineiros.

No artigo, inicialmente, mapeamos um panorama dos gastos municipais com EJA na década de 1990. A seguir, analisamos alguns elementos da política educacional de Minas Gerais para jovens e adultos e, logo, passamos ao estudo da amostra selecionada, contemplando: condições de oferta da sua rede municipal de ensino (aspectos socioeconômicos e educacionais); sua capacidade financeira; e seu gasto público em educação (de jovens e adultos). Finalmente, esboçamos as interpretações possíveis com base em "dados".

\section{GASTOS DOS MUNICÍPIOS COM EJA}

Por imposição legal e pressão social, os municípios passaram a atender a população jovem e adulta oferecendo, sobretudo, os anos iniciais da escolarização básica. A pressão ocorreu por diversos movimentos da sociedade civil, movimentos sociais e sindicais, pressões de redes de atores comunitários e de famílias. Proliferaram-se os projetos e propostas; um panorama multifacetado de ações que podiam conter inovação e criatividade, porém com pouca estabilidade institucional; mais amarradas às condições que as produziram do que à constituição de um sistema nacional, de uma política nacional para jovens e adultos (Haddad, 2007).

Além disso, esse processo não foi acompanhado de proporcional aumento de recursos (financeiros e técnicos) necessários para a sua viabilização. Em outras palavras, descentralização das responsabilidades desacompanhada dos recursos financeiros adequados para concretizá-la.

Nesse sentido, um estudo do Instituto Brasileiro de Administração Municipal (IBAM) sobre o Panorama das finanças municipais em 2002, de François Bremaeker (2003a), conclui que os estados foram transferindo parte de suas responsabilidades para os municípios sem a correspondente transferência de recursos. Paralelamente, a União criou mecanismos financeiros que retiraram recursos dos estados e dos municípios, a saber: novas contribuições e aumento de alíquotas já existentes que não fossem 
compartilhadas; adoção de uma farta renúncia fiscal com os impostos que constituíam o Fundo de Participação dos Municípios (FPM) e o Fundo de Participação dos Estados (FPE); apropriação de recursos expressivos com a criação do Fundo Social de Emergência (FSE), transformado em Fundo de Estabilização Fiscal (FEF) e, a seguir, em Desvinculação de Receitas da União (DRU); desoneração do Imposto sobre Circulação de Mercadorias e Serviços (ICMS) sobre produtos primários e semielaborados com a Lei Kandir (lei complementar n. 87/1996); intensificação da cobrança das dívidas contraídas no passado. O autor observa que com a Lei de Responsabilidade Fiscal (lei complementar n. 101/2000) ficou mais difícil praticar a renúncia fiscal, mas continuou existindo a possibilidade de utilização de outros mecanismos que podiam trazer prejuízo para o financiamento para estados e municípios.

Em estudo anterior, também para o IBAM, o mesmo Bremaeker (2003b) já havia constatado um despautério: despesas municipais com funções de competência da União e dos estados, em 2002, na área da educação; a saber: a) cessão de professores para escolas estaduais; b) fornecimento de merenda e transporte escolar para os alunos das escolas estaduais; c) manutenção de escolas estaduais; d) cessão de pessoal e manutenção dos serviços estaduais de apoio.

Nessas tramas movimentaram-se os municípios, elevados a entes federados logo, implicados em responsabilidades - pela Constituição Federal de 1988, e objetos de uma saravaida de críticas havia longa data, entre as quais as principais versavam sobre a má aplicação de seus parcos recursos financeiros. José Carlos Melchior (1980, p. 43-44) resume ter se organizado uma ideologia, ora radical, ora cautelosa, com fatos objetivos e subjetivos, que procura demonstrar a incapacidade administrativa de os municípios gerirem seus próprios recursos. Fatores políticos, econômicos, educacionais, morais e religiosos fundamentam as teses antimunicipalistas. ${ }^{1}$ Ocorre, porém, que as críticas ignoram as raízes profundas do "mal" municipal. Analisam-se mais os efeitos que as causas condicionantes, minimizando o ponto nevrálgico de que em nosso desenvolvimento histórico, seja político, administrativo e/ou financeiro, os municípios foram objeto de um processo cujos agentes foram os estados e a União. Logo, a incapacidade administrativa não é característica exclusiva dos municípios, mas talvez neles ela se apresente em maior grau, contudo as administrações públicas federal e estadual não estejam isentas desse "mal".

1 Pontes Miranda (apud Soares, 1986, p. 27) afirma que “o município só existe porque a lei quer". E João Mendes Júnior (idem, ibidem) declara que "os municípios não têm autonomia política, por isso não podem organizar-se. [...] o município, mesmo perante o Direito Público, é um incertum corpus, visto que, em qualquer tempo, pode ser dividido, desmembrado ou limitado por lei do Estado". Na mesma direção, Castro Nunes (apud Aguiar, 1993, p. 9) postula que "o Município não é peça essencial da federação". Por fim, José Afonso da Silva (idem, p. 9-10), crítico da inclusão do município na federação brasileira pela Constituição Federal de 1988, manifesta discordância quanto à concessão de maior autonomia ao município, visto que, para o autor, "não existe federação de municípios. Existe federação de Estados. Estes é que são essenciais ao conceito de qualquer federação". Argumentos contrários e favoráveis à municipalização são resenhados por João Pedro Fonseca $(1990,1997)$. 
Mais diretamente quanto às informações sobre os gastos com EJA nos municípios, Cândido Gomes (1994, p. 14) reuniu dados para os anos de 1988 e 1989, destacando que a esfera local foi a mais sensível ao novo texto constitucional, aumentando suas despesas no ensino supletivo imediatamente após 1988 (de $0,9 \%$ para $4,1 \%$ da despesa municipal na função educação e cultura), quase se equiparando, percentualmente, ao ensino médio (cuja despesa municipal cresceu de 1,9\%, em 1988, para 4,3\%, em 1989). O ensino fundamental manteve a primazia, apesar do crescimento insignificante (a despesa municipal na função educação e cultura no subprograma ensino fundamental cresceu de 85,95\%, em 1988, para 86,0\%, em 1989).

Todavia, considerando os dados levantados por Médici e Maciel (1996, p. 97 apud Di Pierro, 2000a, p. 24) na Fundação do Desenvolvimento Administrativo (FUNDAP)/Instituto de Economia do Setor Público (IESP) para os anos de 1980 a 1990, e por Castro (1999, p. 97 apud idem, ibidem) no Instituto de Pesquisa Econômica Aplicada (IPEA)/Diretoria de Política Social (DIPOS) para o ano de 1995, verificamos que a variação positiva captada foi apenas incidental, visto que numa série mais longa a despesa municipal realizada com o ensino supletivo situava-se em patamares inferiores a $1 \%$ do gasto educacional. Tratava-se de um dos subprogramas com investimentos mais precarizados; o outro era o ensino/ educação especial, em situação pior (exceto em 1990) até mesmo que o ensino superior, competência precípua da União.

Tabela 2 - Brasil: Gastos municipais com educação por subprogramas - 1980/1995 (em \%)

\begin{tabular}{l|r|r|r|r}
\hline \multirow{2}{*}{ Estrutura da Despesa } & \multicolumn{3}{|c|}{ Municípios de Capitais } & Municípios \\
\cline { 2 - 5 } & 1980 & 1985 & \multicolumn{1}{c}{1990} & \multicolumn{1}{c}{1995} \\
\hline Administração & $8,7 \%$ & $18,0 \%$ & $15,4 \%$ & $20,2 \%$ \\
\hline Ensino de $1^{\circ}$ grau/fundamental & $81,4 \%$ & $69,9 \%$ & $73,1 \%$ & $52,4 \%$ \\
\hline Ensino de $2^{\circ}$ grau/médio & $1,1 \%$ & $1,4 \%$ & $0,1 \%$ & $5,2 \%$ \\
\hline Ensino supletivo e EJA & $0,4 \%$ & $0,7 \%$ & $0,3 \%$ & $0,3 \%$ \\
\hline Ensino superior & $1,0 \%$ & $0,6 \%$ & $0,0 \%$ & $1,2 \%$ \\
\hline Assistência ao educando & $7,3 \%$ & $9,2 \%$ & $11,0 \%$ & $2,6 \%$ \\
\hline Ensino/educação especial & $0,2 \%$ & $0,1 \%$ & $0,1 \%$ & $0,7 \%$ \\
\hline Educação criança de 0 a 6 anos & - & - & - & $12,4 \%$ \\
\hline Educação física e desporto & - & - & - & $4,9 \%$ \\
\hline Total & $100 \%$ & $100 \%$ & $100 \%$ & $100 \%$ \\
\hline
\end{tabular}

Fontes: FUNDAP/IESP para 1980 a 1990 (Médici e Maciel apud Di Pierro, 2000a, p. 24); IPEA/DIPOS para 1995 (Castro apud idem, ibidem).

Elaboração da autora.

OBS.: Como as metodologias e critérios dos trabalhos são distintos, as comparações são aproximativas.

Com a adaptação das tabelas 18,19 e 20 propostas por Maria Clara Di Pierro (idem, p. 26-28), podemos sublinhar gastos municipais crescentes em todas as regiões do Brasil: no total, os municípios responderam com recursos próprios a cerca de 86,60\%, 93,90\% e 91,60\% do total investido em EJA em 1994, 1995 e 
1996, respectivamente. Em valores correntes, grande esforço foi realizado pelos municípios da região Sudeste (os municípios da região, apenas com recursos próprios, corresponderam a aproximadamente $46,23 \%, 64,88 \%$ e $65,84 \%$ do total investido em 1994, 1995 e 1996, respectivamente, na modalidade), destacadamente os paulistas (representaram 93,49\%, 78,87\% e 81,13\%, em 1994, 1995 e 1996, respectivamente do total da região Sudeste). No Brasil, as transferências do governo federal foram inexpressivas (queda de aproximadamente 13,40\% para 6,10\% e 8,40\% dos gastos totais em 1994, 1995 e 1996, respectivamente), e as do governo estadual inexistiram para os mesmos anos.

\section{Tabela 3 - Brasil: Gasto público municipal consolidado com EJA por Unidade da Federação - 1994 a 1996}

\begin{tabular}{|c|c|c|c|c|c|c|c|c|c|c|c|c|}
\hline \multirow[b]{3}{*}{$\begin{array}{l}\text { Regiões } \\
\text { e UF's }\end{array}$} & \multirow{2}{*}{\multicolumn{4}{|c|}{1994}} & \multirow{2}{*}{\multicolumn{4}{|c|}{1995}} & \multicolumn{4}{|c|}{ (Em R\$ mil correntes) } \\
\hline & & & & & & & & & & & 996 & \\
\hline & 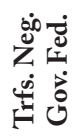 & 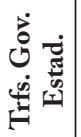 & 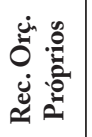 & हี & 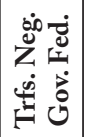 & 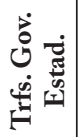 & 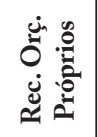 & 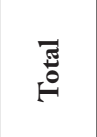 & 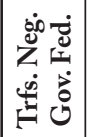 & 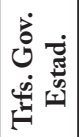 & 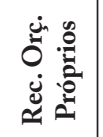 & हีّ \\
\hline Norte & 0 & 0 & 221 & 221 & 0 & 0 & 153 & 153 & 678 & 0 & 710 & 1.388 \\
\hline $\mathrm{RO}$ & & & 21 & 21 & & & & & 251 & & 21 & 272 \\
\hline $\mathrm{AC}$ & & & & & & & & & 211 & & & 211 \\
\hline $\mathrm{AM}$ & & & 110 & 110 & & & & & 50 & & 291 & 341 \\
\hline $\mathrm{RR}$ & & & 90 & 90 & & & & & 4 & & & 4 \\
\hline $\mathrm{PA}$ & & & & & & & 141 & 141 & 50 & & 398 & 448 \\
\hline $\mathrm{AP}$ & & & & & & & & & 77 & & & 77 \\
\hline $\mathrm{TO}$ & & & & & & & 12 & 12 & 35 & & & 35 \\
\hline Nordeste & 0 & 0 & 2.823 & 2.823 & 0 & 0 & 2.845 & 2.845 & 1.223 & 0 & 5.081 & 6.304 \\
\hline MA & & & 190 & 190 & & & 87 & 87 & 43 & & 373 & 416 \\
\hline PI & & & & & & & & & 145 & & 100 & 245 \\
\hline $\mathrm{CE}$ & & & & & & & & & 176 & & & 176 \\
\hline $\mathrm{RN}$ & & & 63 & 63 & & & & & 128 & & 200 & 328 \\
\hline $\mathrm{PB}$ & & & 2.001 & 2.001 & & & 1.414 & 1.414 & 122 & & 1.297 & 1.429 \\
\hline $\mathrm{PE}$ & & & 238 & 238 & & & 1.171 & 1.171 & 59 & & 2.710 & 2.769 \\
\hline $\mathrm{AL}$ & & & 122 & 122 & & & 173 & 173 & 183 & & 272 & 455 \\
\hline $\mathrm{SE}$ & & & & & & & & & 94 & & 129 & 223 \\
\hline $\mathrm{BA}$ & & & 209 & 209 & & & & & 273 & & & 273 \\
\hline Sudeste & 0 & 0 & 6.621 & 6.621 & 0 & 0 & 15.923 & 15.923 & 773 & 0 & 30.479 & 31.252 \\
\hline $\mathrm{MG}$ & & & 392 & 392 & & & 2.197 & 2.197 & 112 & & 3.922 & 4.034 \\
\hline ES & & & & & & & 26 & 26 & 58 & & 19 & 77 \\
\hline $\mathrm{RJ}$ & & & 39 & 39 & & & 1.142 & 1.142 & 111 & & 1.183 & 1.294 \\
\hline SP & & & 6.190 & 6.190 & & & 12.558 & 12.558 & 492 & & 25.355 & 25.847 \\
\hline Sul & 0 & 0 & 1.840 & 1.840 & 0 & 0 & 4.006 & 4.006 & 482 & 0 & 5.519 & 6.001 \\
\hline PR & & & & & & & & & 206 & & 25 & 231 \\
\hline $\mathrm{SC}$ & & & & & & & & & & & 1.491 & 1.491 \\
\hline RS & & & & & & & 4.006 & 4.006 & 276 & & 4.003 & 4.279 \\
\hline
\end{tabular}

(continua...) 


\begin{tabular}{|c|c|c|c|c|c|c|c|c|c|c|c|c|}
\hline \multirow[b]{2}{*}{$\begin{array}{l}\text { Regiões } \\
\text { e UF's }\end{array}$} & \multicolumn{4}{|c|}{1994} & \multicolumn{4}{|c|}{1995} & \multicolumn{4}{|c|}{1996} \\
\hline & 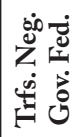 & 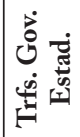 & 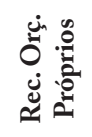 & है & 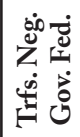 & 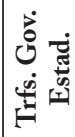 & 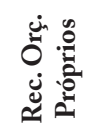 & ฮే & 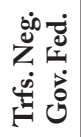 & 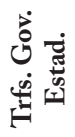 & 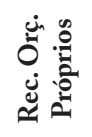 & 吾 \\
\hline C. Oe & 0 & 0 & 901 & 901 & 0 & 0 & 129 & 129 & 312 & 0 & 639 & 951 \\
\hline MS & & & 0 & 3 & & & 72 & 72 & 168 & & 179 & 347 \\
\hline MT & & & & & & & & & 114 & & & 114 \\
\hline $\mathrm{GO}$ & & & 898 & 898 & & & 57 & 57 & 30 & & 460 & 490 \\
\hline DF & & & & & & & & & & & & \\
\hline * & 1.916 & & & 1.916 & 1.486 & & & 1.486 & 401 & & & 401 \\
\hline TOTAL & 1.916 & 0 & 12.406 & 14.322 & 1.486 & 0 & 23.056 & 24.542 & 3.869 & 0 & 42.428 & 46.297 \\
\hline$\%$ & 13,40 & 0,00 & 86,60 & 100,00 & 6,10 & 0,00 & 93,90 & 100,00 & 8,40 & 0,00 & 91,60 & 100,00 \\
\hline
\end{tabular}

Fonte: Instituto Brasileiro de Geografia e Estatística (IBGE)/Departamento de Contas Nacionais (DECNA); IPEA/ DIPOS. Adaptação das tabelas 18, 19 e 20 de Di Pierro (2000a, p. 26-28).

Não foi possível identificar UF nem região.

Elaboração da autora.

Transferências Negociadas Governo Federal (Trfs. Neg. Gov. Fed.)

Transferências de Governos Estaduais (Trfs. Gov. Estad.)

Recursos Orçamentários Próprios (Rec. Orç. Próprios)

\section{ELEMENTOS DA POLÍTICA EDUCACIONAL PARA JOVENS E ADULTOS EM MINAS GERAIS}

A reforma educacional que se desenvolveu na década de 1990 em Minas Gerais ilustra os paradigmas para a educação que consubstanciam as demandas de transformação produtiva com equidade. Logo, o problema é que, embora se tenha adotado no período uma política que se justificava pela busca da igualdade social, esta também acompanhou o mesmo ritmo e lógica excludentes do atual padrão de acumulação. Como provas irrefutáveis desse processo, Dalila Oliveira (2000) considera: a prioridade da educação básica, no Brasil entendida mais na perspectiva de ensino fundamental, em detrimento da educação infantil e do ensino médio; a transferência do atendimento do ensino fundamental para os municípios, com pouca ou nenhuma capacidade de atendimento; e, ainda, condições precárias de trabalho e remuneração dos trabalhadores da educação.

Tomados os cenários externo e interno da reforma educacional mineira da década de 1990, podemos perceber que o Estado não fugiu ao padrão das reformas da década na América Latina:

Na prática, as reformas reduziram o total de recursos públicos e privados disponíveis para o financiamento da educação e da formação de professores. Mas essas reformas tinham mais um objetivo: organizar de modo novo e mais produtivo o aproveitamento escolar e as qualificações profissionais, tendo em vista, sobretudo, produzir capital humano de melhor qualidade a fim de tornar os 
países da América Latina e do Caribe mais competitivos na economia mundial. (Castro; Carnoy, 1997, p. 16)

Para além da equidade social, as expectativas dos sistemas públicos de ensino ao se reformarem giraram em torno de adequá-los às demandas do capital. Essa adequação, todavia, não implicava formação homogênea de trabalhadores; afinal, os requisitos educacionais variam conforme o modelo de exploração adotado ou ainda com as possibilidades ou não de inserção no mercado de trabalho. Assim, se é preciso oferecer uma base educacional para todos, deve-se assegurar o desenvolvimento desigual de capacidades inerentes às exigências do atual estágio das condições gerais de produção (Oliveira, 2000, p. 306).

Quanto à EJA, a diversidade do estado de Minas Gerais e as várias iniciativas disponíveis no país resultaram em diretrizes que orientaram as políticas públicas educacionais mineiras para a modalidade prevendo a instituição de parcerias entre governo federal, municípios, empresas privadas, organizações não governamentais (ONG), organismos internacionais e instituições civis, visando potencializar o compromisso nacional de "erradicar" o analfabetismo e proporcionar educação básica e profissional à população jovem e adulta. As diferenças de oferta e demanda são significativas no estado, que possui 853 municípios e a segunda maior população do país (mais de 19,5 milhões).

O "Diagnóstico de EJA no estado de Minas Gerais", realizado pela Diretoria de Educação de Jovens e Adultos (DEJA) no Documento final do Encontro Mineiro Preparatório à VI CONFINTEA (Fórum..., 2008, p. 20-21), concluiu que:

[...] houve avanços no sistema educacional mineiro, principalmente no aumento do atendimento educacional à população de jovens e adultos e pela melhoria da qualificação do quadro de docentes em nível superior e a valorização dada ao setor público nessa área pela gestão governamental.

De fato, o nível educacional da população de Minas Gerais melhorou, considerando-se a queda da taxa de analfabetismo de 2001 a 2006 (decresceu de $11,67 \%$ para 9,03\%). Segregando-se por faixa-etária, podemos perceber que essa queda ocorreu, sobretudo, entre a população de 15 a 25 anos (caiu de 2,31\%, em 2001, para 1,39\%, em 2006), mas também entre a população acima de 25 anos (oscilou de 15,05\%, em 2001, para 11,50\%, em 2006) (idem, p. 23). Porém, a taxa de analfabetismo por situação de domicílio indicou um elevado percentual de pessoas analfabetas na zona rural mineira, apesar de decrescente $(26,40 \%$, em 2001, para 19,65\%, em 2006) (idem, p. 24).

Ainda segundo o "Diagnóstico" (idem, p. 18), o dado de aproximadamente 1.326.000 de analfabetos com 15 anos ou mais é "muito alto e merecedor de atenção especial nas ações políticas educacionais". O mesmo documento justificou que o fluxo migratório de outros estados para Minas Gerais pudesse ter influenciado o resultado, já que inexiste um censo específico sobre a procedência do indivíduo pesquisado. Mas do que importa a origem do indivíduo; não é ele um compatriota brasileiro? 
Embora o "Diagnóstico"(Fórum..., 2008,p. 20-21) tenha reconhecido a existência da demanda "para investimentos prioritários para a superação da defasagem escolar e a superação de diferenças urbanas e rurais regionais no analfabetismo", o exame que procedemos com bases nas sinopses estatísticas da educação básica de 1997, 2000, 2003 e 2006, do INEP, denuncia uma queda acentuada seguida de recuperação das matrículas nos cursos presenciais de EJA, com avaliação no processo, do estado mineiro, oscilando de 221.173 , em 1997 , para $55.721,80.114$ e 212.931, em 2000, 2003 e 2006, respectivamente. Na verdade, a rede estadual decresceu vertiginosamente entre 1997 e 2003 (62,74\%, 5,10\% e 3,31\% do total de matrículas nos cursos presenciais de EJA, com avaliação no processo, em 1997, 2000 e 2003, respectivamente). A seu turno, a municipal elevou-se de 22,51\%, 34,79\% e 70,49\% em 1997, 2000 e 2003, respectivamente. Finalmente, ambas equivaleram-se em 2006: a rede estadual respondendo por $46,57 \%$ e a municipal por $45,16 \%$ das matrículas. O decréscimo vertiginoso entre o período de 1997 e 2000 foi, em parte, minimizado pela elevação dos matriculados nos cursos preparatórios para exames, em que as matrículas subiram de 3.900 para 90.376, em 1997 e 2000, respectivamente. Sobre esses, não cabe aqui discutir os méritos pedagógicos.

A análise das matrículas nos ensinos fundamental e médio "regular" por faixa etária revelou a presença de um público jovem/adulto considerável. A questão nevrálgica suscitada aqui, porém, é a seguinte: As estruturas administrativas, curriculares e, sobretudo, metodológicas do nível "regular" são adequadas às necessidades distintas dos sujeitos? Em outras palavras, não só os problemas diferentes, mas fundamentalmente expectativas, necessidades e tempos diversos são respeitados ante a imposição de 200 dias letivos, com 4 horas diárias de aula, além da estrutura curricular definida com base no "regular"?

Também as classes de aceleração e de correção de fluxo do ensino fundamental foram empregadas como opção que não pode ser de toda destituída de interesses financeiros pragmáticos - economia de recursos pela redução do tempo de "formação" do aluno e, no caso dos municípios, possibilidade de empregar recursos do FUNDEF. Especificamente em Minas Gerais, tais classes apresentaram percentuais superiores à média nacional, mas com um diferencial: enquanto em 2000 a rede estadual respondeu por 73,07\% das matrículas em classes de aceleração/ correção de fluxo no ensino fundamental, em 2003 e 2006 foi a rede municipal que representou $98,26 \%$ e $100 \%$ delas, respectivamente.

A tendência ascendente do número de matriculados nos cursos presenciais da EJA, com avaliação no processo, apresentou-se muito acentuada em Minas Gerais, onde o total de matrículas saltou de 55.721, em 2000, para 212.931, em 2006; ou seja, um crescimento de cerca de $282,14 \%$. Além disso, a municipalização mostrou-se fenômeno destacado no estado mineiro: a rede estadual que, em 1997, representava $62,74 \%$ das matrículas da modalidade despencou para aproximadamente $5,10 \%$, em 2000 , e voltou a subir a partir de 2004 , respondendo por $20,64 \%, 42,42 \%$ e $46,57 \%$ do total de matrículas, em 2004, 2005 e 2006, respectivamente. Já a rede municipal, que em 1997 representava 22,51\% das matrículas da modalidade, subiu para 34,79\% 
em 2000 e, vertiginosamente, para 70,49\%, em 2003, regredindo a partir de 2004 para 59,77\%,44,49\% e 45,16\%, em 2004, 2005 e 2006, respectivamente. O agravante foi que, apesar do aumento da responsabilidade dos municípios, o decréscimo da rede estadual não foi de todo compensado por estes, mas pelo setor privado, sobretudo em 2000, quando a rede particular respondeu por 59,34\% das matrículas na modalidade; na sequência, 25,95\%, em 2003, e queda vertiginosa para 8,09\%, em 2006. Portanto, podemos inferir que o setor privado emerge nas lacunas deixadas pela esfera pública, mas, sobre suas mazelas de ensino aligeirado e de baixa qualidade possíveis, que não cabe aqui discutir, carecemos de acompanhamento e controle.

Tabela 4 - Minas Gerais: Evolução das matrículas em EJA presencial por dependência administrativa - 2000 a 2006

\begin{tabular}{|c|c|c|c|c|c|c|c|c|c|c|}
\hline \multirow{2}{*}{$\begin{array}{c}\text { Dep. Adm./ } \\
\text { Ano }\end{array}$} & \multicolumn{2}{|c|}{ Federal } & \multicolumn{2}{|c|}{ Estadual } & \multicolumn{2}{|c|}{ Municipal } & \multicolumn{2}{|c|}{ Privada } & \multicolumn{2}{|c|}{ Total } \\
\hline & $\mathrm{N}^{0}$ & $\%$ & $\mathrm{~N}^{0}$ & $\%$ & $\mathrm{~N}^{0}$ & $\%$ & $\mathrm{~N}^{0}$ & $\%$ & $\mathrm{~N}^{0}$ & $\%$ \\
\hline 2000 & 432 & 0,78 & 2.839 & 5,10 & 19.387 & 34,79 & 33.063 & 59,34 & 55.721 & 100 \\
\hline 2001 & 190 & 0,29 & 3.814 & 5,86 & 42.135 & 64,72 & 18.967 & 29,13 & 65.106 & 100 \\
\hline 2002 & 151 & 0,22 & 2.767 & 4,00 & 46.822 & 67,73 & 19.392 & 28,05 & 69.132 & 100 \\
\hline 2003 & 196 & 0,24 & 2.654 & 3,31 & 56.473 & 70,49 & 20.791 & 25,95 & 80.114 & 100 \\
\hline 2004 & 211 & 0,20 & 21.736 & 20,64 & 62.941 & 59,77 & 20.419 & 19,39 & 105.307 & 100 \\
\hline 2005 & 246 & 0,16 & 66.038 & 42,42 & 69.253 & 44,49 & 20.130 & 12,93 & 155.667 & 100 \\
\hline 2006 & 390 & 0,18 & 99.170 & 46,57 & 96.152 & 45,16 & 17.219 & 8,09 & 212.931 & 100 \\
\hline
\end{tabular}

$\mathrm{N}^{o}=$ Número absoluto de matrículas na dependência administrativa; \% = Percentual da matrícula na dependência administrativa em relação ao total do ano.

Fonte: MEC/INEP (baseada nas informações disponíveis em: <http://www.cnm.org.br/educacao/um_edu_matricula. asp>. Acesso em: ago. 2008).

Elaboração da autora.

O crescimento das funções docentes em EJA, que em geral segue a evolução da matrícula e sua esfera, não explicita que muitos professores assumem cargos na modalidade como complementação de horário, sendo raríssimos concursos, planos de carreira e, principalmente, formação específicos.

\section{O ESTUDO DA EJA EM UMA AMOSTRA SELECIONADA}

Finalmente alcançamos a menor célula da federação - do ponto de vista das fronteiras físico-geográficas, mas não das relações de forças políticas, econômicas e sociais -, o município. O cidadão brasileiro, o habitante deste ou daquele estado é, antes de tudo, um munícipe. Nos $5.564^{2}$ municípios brasileiros, eclodem os problemas do país; neles estão encerrados limites, mas também se encontram enormes possibilidades de gestar as respostas mais apropriadas aos problemas educacionais.

Os desafios para estudar os municípios, mesmo que de uma única esfera estadual como é o caso, são enormes; a começar pelo número reduzido de fontes de

2 Segundo IBGE, em 28/1/2009. 
dados, acesso e controle sobre elas - aqui se faz necessário radicalizar a perspectiva de encarar os valores declarados como referentes, sem deixar de acreditar que seus responsáveis foram idôneos na sua contabilização. Além disso, enfrentamos um problema não apenas de natureza numérica, mas que diz respeito à heterogeneidade e à dificuldade de se estabelecer critérios comuns para um conjunto tão amplo e diverso.

Por tudo isso, a princípio parecia impossível encontrar um caminho lógico no emaranhado de dados. Paulatinamente, iluminou-se o caminho a trilhar... Após meses absorvidos pela sistematização das informações disponíveis e relevantes, bem como na construção do banco de dados, o que demandou trabalho de mouro e tempo precioso da pesquisa, foi possível ordenar a análise de modo compreensível ao leitor. Os caminhos trilhados, bem como os percalços enfrentados na constituição da amostragem, não serão aqui descritos, a fim de que se possa reservar o precioso espaço para a exploração dos resultados.

Em síntese, foram tomados como amostra para estudo os municípios que apresentaram maior e menor investimento aluno EJA/2006 em cada uma das 12 mesorregiões. ${ }^{3}$ Portanto, 24 municípios. ${ }^{4}$ É mister destacar que, a fim de tentar preservar-lhes o anonimato, os municípios foram listados alfabeticamente e renomeados de $\mathrm{A}$ a $\mathrm{Z}$.

Sobre esses municípios, perscrutamos e sistematizamos um vasto rol de informações socioeconômicas, educacionais e financeiras, destacadamente para os anos de 1997, 2000, 2003 e 2006, e excepcionalmente 2007 e 2008 como referência de análise para o período posterior em que passa a vigorar o "novo" Fundo - o Fundo de Manutenção e Desenvolvimento da Educação Básica e de Valorização dos Profissionais da Educação (FUNDEB). Consideramos que somente no interior dessa moldura seria possível compreender o financiamento da EJA.

O trabalho de análise dos dados, do qual resultou a organização de diversas tabelas que foram suprimidas desta exposição, pautou-se em três categorias eleitas, quais sejam: as condições de oferta da rede municipal de ensino dos municípios da amostra, a sua capacidade financeira e o seu gasto público em educação (de jovens e adultos).

3 O IBGE divide Minas Gerais em 12 mesorregiões (Campo das Vertentes, Central, Jequitinhonha, Metropolitana,Mucuri,Noroeste, Norte, Oeste, Rio Doce, Sul/Sudoeste de Minas, Triângulo/Alto Paranaíba e Zona da Mata) e 66 microrregióes (consultar informação disponível em: < http://www.mg.gov.br/governomg/ecp/contents.do?even to $=$ conteudo\&idConteudo $=69547 \& \mathrm{chPl}=69547 \&$ termos $=s \& a p p=$ governomg\&tax $=$ 0\&taxn=5922>).

4 Priorizamos os municípios com informações de 1999 a 2006 (primeira categorização realizada), mas quando estes informavam $R \$ 0,00$ de investimento e indicavam matrícula, e não havendo outro valor diferente de $\mathrm{R} \$ 0,00$ na mesorregião, efetuávamos os cálculos para os municípios das duas categorias seguintes, por entender que escolhendo municípios cujo gasto aluno EJA em 2006 foi de $\mathrm{R} \$ 0,00$ já se partia de uma situação que de antemão assinalava estar na presença de um provável "equívoco". A única exceção foi o Vale do Mucuri: como os dados de seus municípios eram muito escassos, efetuamos o cálculo para todos aqueles que apresentavam informação de matrícula e despesa para 2006, a fim de eleger o maior e o menor investimento em EJA do ano. 
Algumas ressalvas: a) os valores foram os declarados pelos municípios que assumiram o compromisso pela sua idoneidade, mas certamente não estão ilesos a certo grau de maquiagem contábil - reitere-se que, no trabalho, encaramos as estatísticas apenas como referencial, um número sub ou superestimado, mas nem por isso menos importante; b) os orçamentos foram autorizativos - portanto, o legislativo pode até autorizar, mas "gastar" (ou não) e "quando" gastar depende basicamente do executivo; e gastar "em que" e "quanto" também compete ao executivo, respeitadas as especificações legais emanadas do legislativo.

No que tange às condiçôes de oferta da rede municipal, foram estabelecidos $\mathrm{e}$ explorados alguns cruzamentos de diversas informações sociais, econômicas, políticas e educacionais importantes, tais como: Índice de Desenvolvimento Humano (IDH), Produto Interno Bruto (PIB), idade dos residentes, analfabetismo e suas características, matrículas dos níveis e da modalidade EJA, entre outras.

É mister destacar que o número absoluto e o percentual de participação da dependência administrativa nas matrículas de EJA no período de 2000 a 2006 revelaram a forte participação do setor particular, com picos de $67,36 \%$ e 55,70\%, em 2000 e 2001, respectivamente - justamente nas lacunas deixadas pela ausência do poder público. A esfera municipal foi significativa em toda a série, assim evoluindo: $31,93 \%, 41,17 \%, 38,53 \%, 60,60 \%, 51,88 \%, 46,27 \%$ e $28,22 \%$, respectivamente, no período de 2000 a 2006; enquanto a dependência administrativa estadual foi diminuta: 0,00\%, 2,99\%,35,20\%, 0,00\%,17,53\%, 27,06\% e 29,51\%. A participação da esfera federal foi irrisória. Analisados caso a caso; porém, há especificidades que não serão aqui contempladas.

Quanto à capacidade financeira, é possível afirmar que, no geral, todos os municípios da amostra apresentaram comportamento assemelhado na direção dos resultados fiscais, apesar da variação da magnitude. Além disso, podemos perceber que apenas nos municípios de maior porte as receitas próprias foram mais representativas que as provenientes de transferências; e que os municípios de menor porte, quer em termos de população ou de PIB, foram mais dependentes dos recursos transferidos pelas demais esferas. Nesse sentido, destacaram-se o ICMS e o FPM como rubricas de receitas mais significativas. A receita bruta concentrou-se nos municípios de maior porte, onde também foram maiores as receitas de arrecadação própria.

Sublinhe-se que, comparando as receitas contabilizadas como transferências multigovernamentais e deduzidas (deduções de receita) relativas ao FUNDEF, verificamos que a maioria dos municípios da amostra não "perdeu" recursos pelo funcionamento do fundo. Além disso, têm importância vital as transferências, dado o percentual que representaram do investimento realizado na função educação.

No que tange ao gasto público em educação (de jovens e adultos), os resultados dos municípios do estado de Minas Gerais consolidados no Finanças do Brasil (FINBRA) - dados contábeis dos municípios da Secretaria do Tesouro Nacional (STN) para os anos de 2006 a 2008 - evidenciaram que o grande esforço realizado pelos municípios mineiros concentrou-se nos níveis fundamental $(76,77 \%, 75,10 \%$ e $74,01 \%$ do total da função educação em 2006, 2007 e 2008, respectivamente) e infantil 
(10,71\%, 10,37\% e 12,05\% do total da função educação em 2006, 2007 e 2008, respectivamente). No que se refere aos gastos com EJA, os percentuais investidos $(0,59 \%$, 0,51\% e 0,43\% do total da função educação em 2006, 2007 e 2008, respectivamente) foram ligeiramente declinantes e próximos aos investidos na educação especial ( $0,59 \%$, 0,47\% e 0,47\% do total da função educação em 2006, 2007 e 2008, respectivamente).

Em contrariedade ao que preconiza a Lei de Diretrizes e Bases da Educação Nacional (LDB) em seu artigo 11, inciso V, para o qual os municípios devem incumbir-se da oferta da educação infantil em creches e pré-escolas e, prioritariamente, do ensino fundamental, "permitida a atuação em outros níveis somente quando estiverem atendidas plenamente as necessidades de sua área de competência e com recursos acima dos percentuais mínimos vinculados pela Constituição Federal à manutenção e ao desenvolvimento do ensino", o esforço dos municípios em relação ao ensino superior $(0,78 \%, 0,73 \%$ e $0,62 \%$ do total da função educação em 2006 , 2007 e 2008, respectivamente) superou os investimentos na EJA, apesar da enorme demanda potencial ainda reprimida de jovens e adultos por educação básica.

\section{Tabela 5 - Minas Gerais: Despesas nas subfunções da educação dos municípios - 2006 a 2008}

\begin{tabular}{l|r|r|r|r|r|r}
\cline { 2 - 7 } & \multicolumn{2}{|c|}{2006} & \multicolumn{2}{c|}{2007} & \multicolumn{2}{c}{2008} \\
\cline { 2 - 8 } & \multicolumn{1}{c|}{$\mathrm{R} \$$} & \multicolumn{1}{c|}{$\mathrm{R} \$$} & $\mathrm{R} \$$ & $\%$ \\
\hline $\begin{array}{l}\text { Ensino } \\
\text { fundamental }\end{array}$ & $3.101 .006 .108,43$ & 76,77 & $3.562 .546 .401,75$ & 75,10 & $4.122 .568 .856,95$ & 74,01 \\
\hline Ensino médio & $63.461 .944,96$ & 1,57 & $53.950 .098,27$ & 1,14 & $73.492 .983,95$ & 1,32 \\
\hline Ensino profissional & $12.909 .284,95$ & 0,32 & $17.918 .661,28$ & 0,38 & $22.551 .601,06$ & 0,40 \\
\hline Ensino superior & $31.472 .657,40$ & 0,78 & $34.468 .959,13$ & 0,73 & $34.743 .037,67$ & 0,62 \\
\hline Educação infantil & $432.638 .891,16$ & 10,71 & $491.800 .231,37$ & 10,37 & $671.102 .586,94$ & 12,05 \\
\hline EJA & $23.943 .463,26$ & 0,59 & $24.219 .383,81$ & 0,51 & $23.879 .446,46$ & 0,43 \\
\hline Educação especial & $23.834 .491,44$ & 0,59 & $22.143 .867,38$ & 0,47 & $26.348 .109,20$ & 0,47 \\
\hline Demais subfunç̃̃es & $350.333 .444,92$ & 8,67 & $536.882 .420,03$ & 11,32 & $595.340 .103,16$ & 10,69 \\
\hline $\begin{array}{l}\text { Total função } \\
\text { educação }\end{array}$ & $4.039 .600 .286,52$ & 100 & $4.743 .930 .023,02$ & 100 & $5.570 .026 .725,39$ & 100 \\
\hline
\end{tabular}

Fonte: Tabela elaborada com base em dados do Ministério da Fazenda. STN. FINBRA (2006, 2007, 2008). Notas: 1) \% do nível/modalidade em relação ao total investido na função educação no ano; 2) As bases de dados dos FINBRA de 2006, 2007 e 2008 consolidavam informações de 842, 825 e 801 municípios mineiros, segundo extrações realizadas em 6/5/2006, 6/6/2007 e 6/6/2008, respectivamente, e não da totalidade de 853 municípios do estado.

Elaboração da autora.

Especificamente no que tange aos municípios da amostra, desmembrando-se a função educação por subfunção, o que foi possível pelo FINBRA a partir de 2005, verificamos que o ensino fundamental realmente se consagrou como "locomotiva", tendo concentrado, em média, 74,15\%,75,13\%,74,11\% e 71,86\% do total da função educação, de 2005 a 2008. Embora surpreenda que as despesas com EJA sejam maiores do que com o ensino médio, a tendência declinante da "mediana" parece sugerir que, na verdade, a situação dos municípios da amostra não melhorou com a entrada em vigor do FUNDEB. 


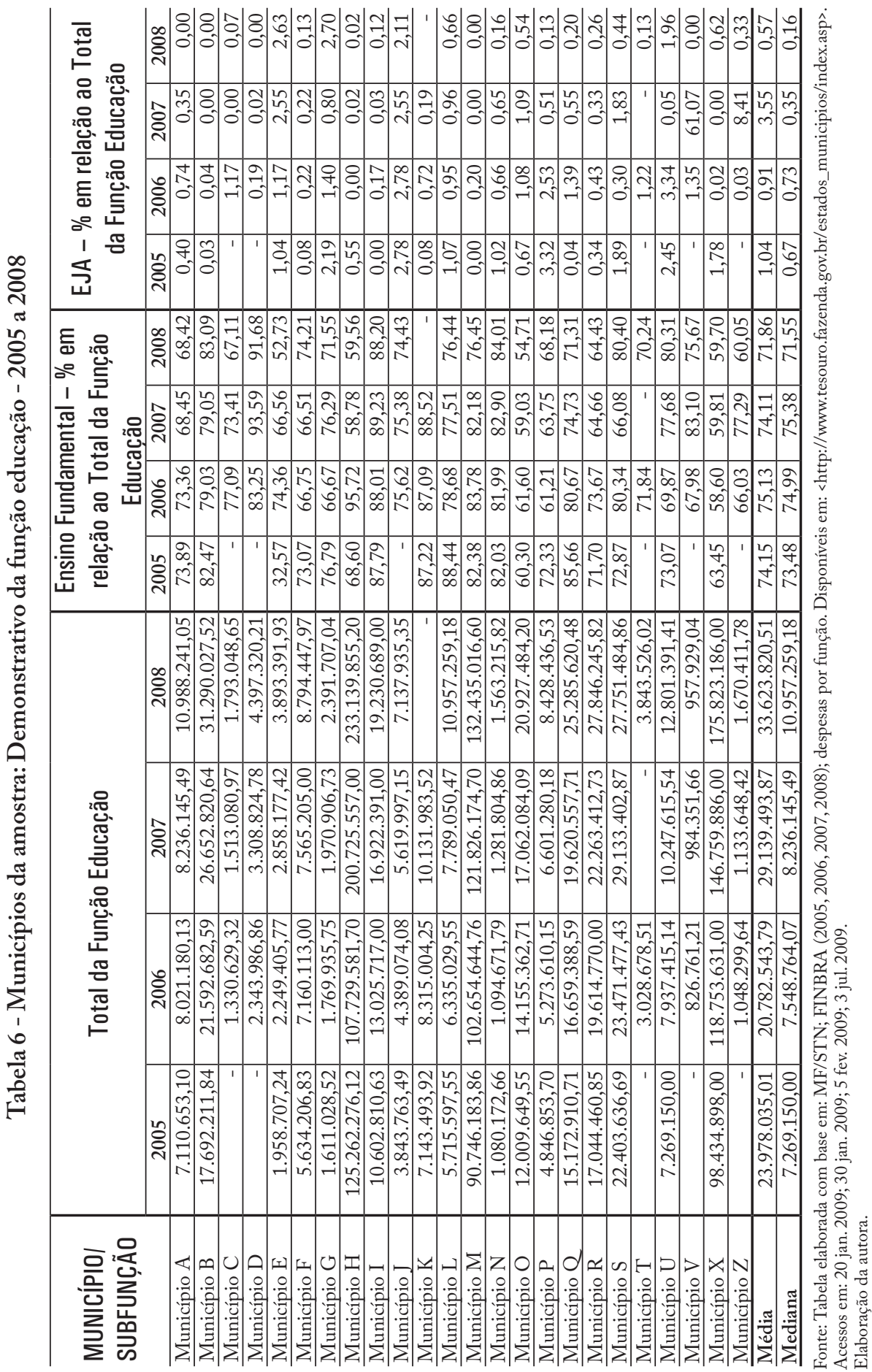


Um indicador profícuo para apreciar a prioridade conferida pelas políticas educacionais é o gasto médio por aluno com recursos públicos. Tomando como referência os dados do FINBRA para valores despendidos e do INEP para matrícula, calculamos o gasto por aluno de EJA para o período de 2005 a 2008, mas não conseguimos estabelecer qualquer padrão de evolução. Evidenciamos, antes, uma grande oscilação nos gastos dos municípios da amostra, quer comparados entre si ou com eles próprios, ano a ano. Acreditamos que a natureza das razões que levaram alguns municípios a gastar centavos e outros, milhares de reais, relaciona-se a fatores políticos, sociais e econômicos presentes, mas não podemos precisá-los. Foram utilizados para ampliação/melhorias da rede física? Foram investidos em equipamentos ou qualificação/treinamento? Financiaram alunos de outras esferas (federal, estadual ou particular)? Ou simplesmente se perderam em práticas de má versação de verba pública e/ou corrupção?

Tabela 7 - Municípios da amostra: Gastos por aluno EJA - 2005 a 2008

\begin{tabular}{|c|c|c|c|c|}
\hline & 2005 & 2006 & 2007 & 2008 \\
\hline Município A & 136,73 & 473,09 & - & 0,00 \\
\hline Município B & - & 59,45 & 0,00 & 0,00 \\
\hline Município C & - & $1.040,92$ & 0,00 & 40,83 \\
\hline Município D & - & 88,88 & 7,31 & 0,00 \\
\hline Município E & 814,40 & $1.093,50$ & - & $2.693,91$ \\
\hline Município F & 43,08 & 248,50 & 155,18 & 43,72 \\
\hline Município G & 483,24 & 345,25 & 276,99 & 538,55 \\
\hline Município H & 335,13 & 0,71 & 4,39 & 4,95 \\
\hline Município I & 0,00 & 21,52 & 4,45 & 23,18 \\
\hline Município J & 266,99 & 260,74 & 519,99 & 633,82 \\
\hline Município K & 173,83 & 209,96 & 88,87 & - \\
\hline Município L & 103,67 & 138,41 & 219,08 & 190,81 \\
\hline Município M & - & 19,10 & 0,39 & 0,43 \\
\hline Município N & 582,46 & 483,83 & 519,70 & - \\
\hline Município O & $4.252,75$ & $1.888,32$ & $3.802,77$ & $2.298,63$ \\
\hline Município P & 274,79 & 238,18 & 75,83 & 20,72 \\
\hline Município Q & 94,69 & $2.937,62$ & 141,26 & 63,72 \\
\hline Município R & $1.302,28$ & $2.157,95$ & $1.725,81$ & $1.226,33$ \\
\hline Município S & 355,07 & 44,00 & 440,63 & 108,23 \\
\hline Município T & - & $1.086,78$ & - & - \\
\hline Município U & 307,44 & 352,52 & 314,64 & 298,63 \\
\hline Município V & 130,90 & 260,29 & 149,47 & 0,00 \\
\hline Município X & $45.042,79$ & 5,22 & 161,60 & 308,33 \\
\hline Município $\mathrm{Z}$ & - & 4,92 & - & - \\
\hline Média & $3.038,90$ & 560,82 & 430,42 & 424,74 \\
\hline Mediana & 291,12 & 254,40 & 152,33 & 53,72 \\
\hline
\end{tabular}

Fonte: Tabela elaborada entendendo gasto aluno EJA como total da despesa na subfunção dividido pelo total de matrículas da rede, considerando como fontes: 1) matrícula em EJA municipal: INEP. Sistema de consulta à matrícula do Censo Escolar (1997-2009). Disponível em: <http://www.inep.gov.br/basica/censo/Escolar/Matricula/>; 2) despesas na subfunção EJA 2006 a 2008: MF./STN.FINBRA (2006, 2007, 2008). Disponíveis em: <http://www.tesouro.fazenda.gov.br/estados_municipios/ index.asp>. Acesso em: out./nov. 2007 (para os anos de 2006 e 2007) e jul. 2009 (para o de 2008).

Elaboração da autora. 
Por fim, é mister observar como esses valores (considerar as medianas já que as médias foram muito inflacionadas pelos gastos elevados informados por alguns municípios) ficaram aquém dos valores mínimos por aluno fixados para o ensino fundamental regular. Enquanto o decreto n. 5.299, de 7 de dezembro de 2004, determinou para 2005 um gasto aluno/ano do ensino fundamental regular (urbano ou rural), de $1^{\text {a }}$ a $4^{\mathrm{a}}$, de $\mathrm{R} \$ 564,63$, e de $5^{\mathrm{a}}$ a $8^{\mathrm{a}}$ de $\mathrm{R} \$ 592,86$, a mediana do gasto aluno EJA/ano dos municípios da amostra no mesmo ano foi de $\mathrm{R} \$ 291,12$. O decreto n. 5.690, de 3 de fevereiro de 2006, definiu para 2006 um gasto aluno/ano do ensino fundamental das séries iniciais urbanas, iniciais rurais, finais urbanas, finais rurais e educação especial, urbana ou rural, respectivamente, $R \$ 682,60, R \$ 696,25$, $\mathrm{R} \$ 716,73, \mathrm{R} \$ 730,38$ e $\mathrm{R} \$ 730,38$, mas a mediana do gasto aluno EJA/ano em 2006 foi de apenas $\mathrm{R} \$ 254,40$. $\mathrm{E}$ foram ainda mais distantes dos valores estimados para EJA (com avaliação no processo e integrada à educação profissional de nível médio) a partir da entrada em vigor do FUNDEB: o decreto n. 6.091, de 24 de abril de 2007, e a portaria interministerial n. 1.027, de 17 de agosto de 2008, definiram um gasto para a modalidade em Minas Gerais, para 2007 e 2008, respectivamente, de $\mathrm{R} \$ 851,16$ e $\mathrm{R} \$ 990,52$. Contudo, os municípios da amostra resultaram numa mediana de gastos aluno EJA/ano de irrisórios $\mathrm{R} \$ 152,33$ e $\mathrm{R} \$ 53,72$, para 2007 e 2008, respectivamente.

\section{INTERPRETANDO OS “DADOS”}

Procurando situar o financiamento da EJA em seus enlaces com o plano social, político, econômico e educacional, observamos mudanças no quadro jurídico-administrativo e consequentes resultados nos gastos públicos envolvidos e da oferta educacional medida pela matrícula. Logo, percebemos que as diretrizes assinaladas por Di Pierro (2001) para analisar as tendências nas políticas públicas de EJA relacionam-se intrinsecamente à problemática do seu financiamento.

Podemos começar discutindo a diretriz de focalização no ensino fundamental "regular" e, no interior dos projetos voltados para a EJA, das populações beneficiárias por idade (mais jovens) e regiões (socioeconomicamente desfavorecidas). O texto constitucional estendeu o ensino fundamental aos jovens e adultos que não o tiveram nas "idades próprias", reconhecendo a EJA como modalidade (portanto integrante) da educação básica. Mas a que se assistiu foi a "priorização excludente" do fundamental "regular" para a faixa etária tida como "regular", até mesmo com a subvinculação de recursos do FUNDEF.

A esse respeito, entendemos ser inútil depositar exclusivamente na dinâmica demográfica a expectativa de superação do analfabetismo, já que o número de analfabetos que decresce pela sucessão geracional vem sendo reposto no mesmo ritmo pela exclusão promovida pelo sistema educativo sobre as novas gerações (Souza, 1999). O analfabetismo - absoluto e funcional - não constitui simplesmente um problema residual, uma dívida do passado, mas uma questão complexa do presente 
a exigir políticas públicas consistentes, duradouras e articuladas a estratégias outras de desenvolvimento econômico, social e cultural (Haddad; Di Pierro, 2000, p. 31).

Se pleiteamos ser a escola uma das instâncias de democratização da sociedade e de promoção de uma educação de qualidade para "todos", como ignorar os milhões de jovens e adultos que não concluíram sequer o ensino fundamental e estão muito aquém do ensino médio?

Quanto à diretriz de privatização, na EJA ela se traduziu de forma mais indireta. Sempre presente, assistimos ao deslocamento da escolarização de jovens e adultos para o terreno dos programas assistenciais que visam atenuar os efeitos perversos da exclusão social; o que é temerário. Se é preciso reconhecer que tais programas têm espaço por suas características de inovação e atendimento, eles não podem substituir a ação do Estado, mas antes complementá-la. Do contrário, compromete-se o dever legal do Estado de assegurar o direito universal à educação fundamental pública, laica e de qualidade. Nesse sentido, no arcabouço jurídico-administrativo que se delineou ao longo do período focalizado para estudo (1996 a 2006) transparece um:

[...] caminho de destituição de direitos e deslegitimação da Educação de Jovens e Adultos como uma política pública e gratuita acompanhado por uma crescente visibilidade de programas compensatórios, seja no campo da filantropia, seja no das políticas de formação das empresas. É este o sentido do Programa Alfabetização Solidária e dos programas ao estilo Gente que Faz. (Haddad, 2002, p. 126)

E, finalmente, a diretriz de descentralização. Jorge Castro e Bruno Duarte (2007) constataram o caráter descentralizado das ações governamentais na área de educação, com estados e municípios sendo as instâncias federadas que mais se ocuparam da oferta educacional, tendo respondido pela maioria dos gastos, comprometendo parcela considerável de seus recursos não financeiros para a educação. $\mathrm{Na}$ EJA revelou-se a pouca importância dos recursos aplicados pelo governo federal no seu financiamento. Dessa forma, a transferência muito rápida e crescente das responsabilidades educacionais em direção aos municípios, sobretudo em relação ao ensino fundamental, configurou um processo de intensa municipalização, com estados e União perdendo importância relativa na gestão de recursos e na oferta da educação. $\mathrm{Na}$ EJA não foi diferente.

A série histórica de evolução das matrículas em EJA, de 2000 a 2006, segundo a unidade administrativa, aqui apresentada anteriormente (Tabela 1), evidencia a tendência declinante e inexpressiva da participação federal. O tímido crescimento da matrícula na rede estadual contrasta com a vultuosidade apresentada pela esfera municipal. Daí a relevância do estudo empírico proposto no trabalho.

Os avanços relativos à descentralização da gestão (e, logo, do financiamento) fundamentam-se na perspectiva de que esse processo geraria círculos virtuosos. Ele otimizaria recursos pela eliminação de atividades-meio, promoveria maior efetividade das políticas ao transferir para a ponta do sistema - para os beneficiários - a 
responsabilidade pela definição de prioridades e tornaria o processo mais transparente, fomentando o acompanhamento e o controle da aplicação dos recursos e da prestação de serviços pela população local (Castro; Duarte, 2007).

Todavia, a rápida transferência de recursos de matrículas inviabilizou a necessidade de tempo para que os municípios se preparassem adequadamente para assumir tanta responsabilidade. A descentralização em direção ao município, em geral, culminou na perda de escala e escopo para a implementação de ações importantes, por exemplo, formação de professores e outros profissionais da educação. Além disso, os conselhos municipais assumiram significativa importância como órgão de controle do adequado uso dos recursos e da prestação de serviços. O problema é que nos municípios, sobretudo nos pequenos, que são a maioria no país, inexiste uma sociedade civil organizada. Dessa forma, muitos desses órgãos estão descaracterizados de sua função fiscalizadora e moralizante, visto serem formados por indivíduos vinculados aos mesmos grupos que controlam o poder local (idem).

Constituiria apelo fácil lançar pedras contra os municípios. Ao contrário, optamos por uma investigação mais profunda com o estudo, que procuramos tão cauteloso, de uma amostragem. Não nos compete defender ou condenar a municipalização ou pior, o município, mas antes procurar diagnosticar o processo e o ente subnacional no que se refere à legislação educacional, destacadamente do financiamento, para refletir sobre suas dificuldades políticas, técnicas e financeiras, bem como sobre suas possibilidades de gestação de uma política que ampare processos educacionais de qualidade para jovens e adultos.

O regime de colaboração entre as esferas proclamado na legislação, que deveria ser exercido pelo governo federal para tentar corrigir a desigualdade da oferta educacional, teve pouquíssimos recursos. No caso da EJA, a indefinição de sua "paternidade" na LDB n. 9.394/1996 dificilmente possibilitaria a responsabilização direta de um dos entes federativos (União, estados ou municípios) pelo não atendimento das suas atribuições constitucionais.

Ademais, é preciso insistir sobre a necessidade da continuidade do envolvimento da União na EJA analfabetos (e pouco escolarizados, acrescentamos); uma atuação solidária entre os sistemas de ensino não deve ser ignorada pelas autoridades educacionais. Compete à União determinar as diretrizes da política de educação básica como um todo, independentemente de idade, e contribuir para a criação das condições necessárias à sua implementação, ainda que a responsabilidade final das ações seja dos estados ou dos municípios (Beisiegel, 1997, p. 244).

A assunção da EJA nos municípios polariza uma tensão: se, por um lado, aproxima os servidores públicos da demanda e do controle da sociedade, favorecendo sua democratização ao potencializar a participação social nas instituições locais de poder; por outro, pode reforçar as desigualdades no atendimento se abandonar aos

5 Os artigos 37 e 38 da seção V ("Da Educação de Jovens e Adultos") do capítulo II ("Da Educação Básica") referem-se genericamente a "sistemas de ensino" e "Poder Público". 
gestores municipais a tarefa de universalizar a educação básica sem contar com os recursos necessários para tanto (Haddad, 2007).

Retomando a questão dos recursos, cabe questionar: Como se procedeu a alocação dos recursos? Destacamos ao longo do trabalho que o sistema de alocação dos recursos financeiros depende consideravelmente de decisões situadas na esfera política. Assim sendo, embora o grau de atividade do sistema econômico expresse maior ou menor possibilidade de financiar ações, nos últimos anos seu incremento não beneficiou o sistema social. Melchior (1987), referindo-se ao período de 1965 a 1982, corrobora evidências nesse sentido, concluindo que justamente nos momentos de maior crescimento do PIB, verificou-se uma decrescente aplicação de recursos em educação, sobretudo pela esfera federal. Os estados e municípios, apesar do esforço crescente, esgotaram sua capacidade de investir na função educação.

Não seria demais, pois, situar o cerne da questão do financiamento da educação para pessoas jovens e adultas no Brasil na falta de vontade política dos governos e da classe dominante que representam, de ofertar uma educação estatal de qualidade para todos, o que somente seria plenamente possível numa sociedade regida por uma lógica de atendimento às necessidades materiais e culturais de todos, diversas das demandadas pelo sistema capitalista. Portanto, a qualidade desigual do ensino estatal e as lacunas na EJA não são fortuitas!

As expectativas geradas pela Constituição Federal de 1988 e sobrelevadas pelas metas estratosféricas esboçadas no Plano Nacional de Educação (PNE) - lei n. 10.172/2001 (Brasil, 2001) - foram ceifadas pelo veto presidencial à inclusão das matrículas de EJA para fins de recebimento do FUNDEF. A eterna retórica política desacompanhada de ações concretas... E pior, assistimos ao afastamento da esfera federal, historicamente grande indutora das iniciativas na área.

Além disso, podemos observar descontinuidade, fragmentação e secundarização dos programas para EJA desenvolvidos pelo MEC, condenando o trabalhador brasileiro à condição de não lugar próprio no cenário educacional brasileiro. Para Sonia Rummert e Jaqueline Ventura (2007, p. 40-41) “[...] um rearranjo do mesmo pensamento hegemônico que tem gerado, ao longo da história, um conjunto de propostas com vistas a atender, prioritariamente, às necessidades do capital nos países periféricos ou semiperiféricos", amenizando as tensões sociais e os impasses inerentes ao sistema capitalista. Modo de manter a população à margem do processo de escolarização cambiado por mecanismos de certificação.

Consideramos que, historicamente, o financiamento da EJA mostrou-se mais reativo (resposta a uma demanda instaurada por pressão socioeconômica) do que pró-ativo (em reconhecimento a um direito). Portanto, a bandeira hasteada jurídica e discursivamente da EJA como direito público subjetivo "não pegou", não resultando em ações concretas efetivas. Fosse a EJA entendida como direito, os investimentos não seriam tão baixos em relação a outros níveis e modalidades de ensino; seria investido muito mais tendo em vista a demanda potencial; seriam evitados os dissabores de cortes orçamentários de cunho economicista ou manobras políticas corporativistas, alimentadas por oblíquos fins eleitoreiros. 
No caso dos entes subnacionais, contudo, é mister ressalvar que a vontade de governadores e prefeitos esbarra num universo ampliado de problemas de toda sorte (educacionais, sociais, políticos, econômicos) e na limitação da capacidade financeira de suas esferas administrativas.

No período em foco, os investimentos em EJA apresentaram-se significativamente reduzidos em relação ao montante de recursos da educação (na média, patamares inferiores a $1 \%$ do gasto). $\mathrm{O}$ gasto federal com a EJA se manteve em níveis bastante baixos em comparação com outras etapas e modalidade de ensino, embora tenha mudado de magnitude, saltando de uma média em torno de $\mathrm{R} \$ 25$ milhões no triênio 1998/2000 para cerca de 400 milhões no triênio 2001/2003, em virtude, sobretudo, dos programas Recomeço e Alfabetização Solidária. Após, despenca para algo em torno de $\mathrm{R} \$ 7$ ou 33 milhões. ${ }^{6} \mathrm{E}$, em 2005 , volta a crescer astronomicamente, alcançando $\mathrm{R} \$ 889.637 .911$ (Di Pierro, 2000b).

Em relação aos municípios da amostragem, não conseguimos perceber um padrão de evolução dos gastos em EJA; na verdade, os gastos dos municípios da amostra com EJA oscilaram consideravelmente, quer comparados entre si, quer ao longo de sua própria série histórica perscrutada.

Apesar da grande variação das magnitudes gastas pelos entes subnacionais, concluímos com o valor irrisório dos gastos com EJA - logo, com seus educandos em comparação aos valores investidos em outros níveis e modalidades de ensino.

Entendemos que a modalidade EJA, com suas especificidades, foi em parte descaracterizada pelos níveis fundamental e médio, o que se revelou pela desagregação de matrículas por idades. Isso aponta para a urgência de se repensar a contabilidade pública, a fim de melhor aferir as informações, especialmente porque o problema foi ratificado por uma medida política (o veto à EJA no FUNDEF), estimulando essa contagem indevida.

Ao final do período em destaque, um item importante da agenda educacional foi a substituição do FUNDEF pelo FUNDEB, como estratégia de sustentabilidade financeira da educação básica. Em outras palavras, a continuidade da política de fundos com expressão estadual como estratégia para dinamizar o financiamento dos gastos em educação (Castro; Duarte, 2007, p. 22).

Particularmente no que diz respeito ao financiamento da EJA pelo FUNDEB, preocupa o coeficiente de distribuição ${ }^{7}$ e o limitador ${ }^{8}$ presentes na lei

6 A mesma fonte (MF/STN/SIAFI/DTDIE/INEP) informa como gasto na subfunção EJA ora R $\$ 7.464 .650$ (em <http://www.inep.gov.br/estatisticas/gastoseducacao/>), ora R $\$ 33.833 .537$ (em <http://www.inep.gov.br/estatisticas/gastoseducacao/despesas_ publicas?P.S._federal.htm>).

7 Ponderações entre diferentes etapas, modalidades e tipos de estabelecimento de ensino adotam como referência o fator 1 para os anos iniciais do ensino fundamental urbano. As demais resultam da multiplicação deste fator de referência por um fator específico entre 0,70 e 1,30 , fixado ano a ano.

8 "A apropriação dos recursos pela educação de jovens e adultos [...] observará, em cada Estado e no Distrito Federal, o percentual de até 15\% (quinze por cento) dos recursos do Fundo respectivo" (Brasil/MEC, 2007, p. 7). 
n. 11.494/2007, mas ainda é prematura a avaliação de seus efeitos. Não menos incipiente, porém, é a conviç̧ão de que o FUNDEB fomentará a EJA; trata-se de um passo demasiado largo, sobre o qual é prudente exercer o "pessimismo da razão" e considerar que as incertezas não são menores que as esperanças - alguns valores numéricos que exploramos no trabalho ratificam esse temor. Sublinhe-se que os dados dos municípios da amostra revelaram que, nos dois primeiros anos do FUNDEB (2007 e 2008), os resultados foram piores que nos dois últimos do FUNDEF (2005 e 2006). Comparando as medianas (já que as médias foram muito inflacionadas pelos gastos muito altos informados por alguns municípios), vemos que os valores decrescem ano a ano: $\mathrm{R} \$ 291,12$, em 2005; $\mathrm{R} \$ 254,40$, em 2006; $\mathrm{R} \$ 152,33$, em 2007 e $\mathrm{R} \$ 53,72$, em 2008.

Indubitavelmente, o FUNDEB abre uma porta mais ampla que a outrora fechada pelo FUNDEF para a modalidade (não apenas traça ponderações para a EJA com avaliação no processo, mas também prevê EJA integrada à educação profissional de nível médio), o que "talvez" chame a atenção dos gestores, mas não os obriga a um compromisso.

Enfim, o financiamento da EJA íntegro, contínuo, na perspectiva que reconhece o direito público subjetivo de TODOS escolarizarem-se, independentemente da idade, é dimensão ainda não concretizada da democratização do Estado brasileiro. Nesse sentido, continua premente revermos a condição da EJA enquanto modalidade que goza apenas dos "farelos de migalhas"; de expectante dos sobejos dos níveis regulares de ensino: recursos financeiros, administrativos e humanos; ociosidade de salas; mera complementação de cargas horárias de professores e toda sorte de profissionais sem formação específica.

Desejamos que os limites do que se pôde fazer pela EJA até o momento (destacadamente, a "possibilidade" de seu financiamento pelo FUNDEB) não embruteçam nosso compromisso moral, histórico e político de continuar perseguindo "viabilizar alguns impossíveis de agora" (Freire, 2001, p. 108).

Novas lacunas se abriram com esta pesquisa. Como perspectiva futura de sua continuidade, sugerimos uma maior aproximação dos municípios da amostra destacadamente daqueles cuja excepcionalidade (positiva ou negativa) dos dados tenha chamado a atenção. Acreditamos que nos aguardam surpreendentes revelações, novas dimensões não alcançadas sobre esse intrincado emaranhado dos (des) caminhos percorridos pelas dotações públicas no financiamento da EJA no Brasil.

\section{REFERÊNCIAS}

Afonso, José Roberto Rodrigues et al. Municípios, arrecadação e administração tributária: quebrando tabus. Revista do BNDES, Rio de Janeiro: BNDES, v. 5, n. 10, p. 3-36, dez.1998a. .; Ramundo, Júlio César Maciel; Araujo, Erika Amorim. Breves notas sobre o federalismo fiscal no Brasil. [S.1.]: [s.n.],1998b. Disponível em: <http://www.federativo.bndes. gov.br/f_estudo.htm>. Acesso em: ago. 2004. 
Aguiar, Joaquim Castro. Competência e autonomia dos municípios na nova constituição. Rio de Janeiro: Forense, 1993.

Beisiegel, Celso de Rui. A política de educação de jovens e adultos analfabetos no Brasil.In: Oliveira, Dalila Andrade (Org.). Gestão democrática da educação: desafios contemporâneos. Petrópolis: Vozes, 1997. p. 207-245.

Brasil. Presidência da República. Casa Civil. Subchefia para Assuntos Jurídicos. Lei n. 9.394, de 20 de dezembro de 1996. Estabelece as diretrizes e bases da educação nacional. Diário Oficial da União, Brasília, 23 dez. 1996. Disponível em: <www.planalto.gov.br/ ccivil_03/leis/19394.htm>. Acesso em: 5 dez. 2007.

Presidência da República. Casa Civil. Subchefia para Assuntos Jurídicos. Lei n. 10.172, de 9 de janeiro de 2001. Aprova o Plano Nacional de Educação e dá outras providências. Diário Oficial da União, Brasilia, 10 jan. 2001. Disponível em: <http://www. planalto.gov.br/ccivil_03/leis/leis_2001/110172.htm>. Acesso em: jul. 2012.

. Decreto n. 5.690, de 3 de fevereiro de 2006. Fixa o valor mínimo anual por aluno de que trata o art. $6^{\circ}, \S 1^{\circ}$, da lei n. 9.424 , de 24 de dezembro de 1996 , para o exercício de 2006, e dá outras providências. Diário Oficial da União, Brasília, 6 fev. 2006. Disponível em: <http://www.planalto.gov.br/ccivil_03/_Ato2004-2006/2006/Decreto/D5690.htm>. Acesso em: 3 jun. 2006.

MEC. Lei n. 11.494, de 20 de junho de 2007. Diário Oficial da União, Poder Executivo, Brasília, 21 jun. 2007. Seção 1, edição n. 118, p. 7.

. Decreto n. 6.091, de 24 de abril de 2007. Define e divulga os parâmetros anuais de operacionalização do FUNDEB, para o exercício de 2007. Diário Oficial da União, Brasilia, 25 abr.2007.Disponível em: <http://www.planalto.gov.br/ccivil_03/_Ato2007-2010/2007/ Decreto/D6091.htm>. Acesso em: 3 jun. 2007.

. Ministério da Fazenda. Secretaria Tesouro Nacional. Perfil e evolução das finanças municipais: 1998-2006 (Versão preliminar não submetida à discussão prévia). Brasília: [s.n.], out. 2007. Disponível em: <http://www.tesouro.fazenda.gov.br/estados_municipios/index. asp>. Acesso em: 29 abr. 2009.

. Presidência da República. Casa Civil. Subchefia para Assuntos Jurídicos. Portaria interministerial n. 1.027, de 19 de agosto de 2008. Diário Oficial da União, Brasília, 20 ago. 2008. Seção 1, p. 19-20.

Bremaeker, François E. J. de. Panorama das finanças municipais em 2002. Rio de Janeiro: IBAM; APMC; NAPI; IBAMCO, 2003a. (Estudos especiais, 57). Disponível em: <http:// area/pmc/articul/estepec/espe057p.doc>. Acesso em: jan. 2008.

. Despesas municipais com as funçôes de competência da União e dos estados em 2002. Rio de Janeiro: IBAM; APMC; NAPI; IBAMCO, 2003b. (Estudos especiais, 56). Disponível em: <http://area/pmc/articul/estepec/espe056p.doc>. Acesso em: jan. 2008.

Castro, Cláudio Moura; CARnoy, Martin. Como anda a reforma da educação na América Latina? Rio de Janeiro: FGV, 1997. 
Castro, Jorge Abrahão de; Duarte, Bruno de Carvalho. Descentralização da educação pública no Brasil: evolução dos gastos e matrículas. In: Reunião DA ANUAL DA ANPEd, 30., 7 a 10 de outubro de 2007, Caxambu. Anais... Rio de Janeiro: ANPEd,2007.25p. Disponível em: <http://www.anped.org.br/reunioes/30ra/trabalhos_encomendados/trabalho\%20 encomendaen\%20gt04\%20-\%20int.pdf>. Acesso em: fev. 2011.

Di Pierro, Maria Clara. O financiamento público da educação básica de jovens e adultos no Brasil no período 1985/1999. In: Reunião Anual DA ANPEd, 23., 2000, Caxambu. Anais... Rio de Janeiro: ANPEd, 2000a. 30p. Disponível em: <http://www.anped.org.br/ reunioes/23/textos/1806t.PDF>. Acesso em: nov. 2000.

As políticas públicas de educação básica de jovens e adultos no Brasil do período 1985/1999. 2000. Tese (Doutorado em Educação) - Pontifícia Universidade Católica de São Paulo, São Paulo, 2000b.

Descentralização, focalização e parceria: uma análise das tendências nas políticas públicas de educação de jovens e adultos. Educação e Pesquisa, São Paulo: FEUSP, v. 27, n. 2, p. 321-337, jul./dez. 2001.

Farenzena, Nalú. Descentralização e federalismo: algumas implicações para as responsabilidades (inter)governamentais no financiamento da educação brasileira. In: Peroni, Vera Maria Vidal; Pegoraro, Ludimar; Bazzo, Vera Lucia (Org.). Dilemas da educação brasileira em tempos de globalização neoliberal: entre o público e o privado. Porto Alegre: UFRGS, 2006, p. 49-58.

Fonseca, João Pedro.Municipalizar, verbo transitivo. Educação e Pesquisa, São Paulo: FEUSP, v. 16, n. 1/2, p. 132-147, jan./dez. 1990.

Municipalização do ensino: entre medos e esperanças às vésperas do terceiro milênio. Revista Brasileira de Política e Administração da Educação, Recife: ANPAE, v. 13, n. 2, p. 149-184, 1997.

Fórum Mineiro de EJA e SEE/MG. Documento final do Encontro Mineiro Preparatório à VI CONFINTEA. Belo Horizonte, 28 e 29 de março de 2008. Disponível em: <http:// forumeja.org.br/mg/sites/forumeja.org.br.mg/files/docmg.pdf>. Acesso em: ago. 2009.

Freire, Paulo. Política e educação. 6. ed. São Paulo: Cortez, 2001. (coleção Questões da Nossa Época, v. 23).

Gomes, Cândido Alberto. Os caminhos e descaminhos dos recursos financeiros em educação. Revista Brasileira de Estudos Pedagógicos, Brasilia: INEP, v. 75, n. 179/180/181, p. 9-32, jan./dez. 1994.

Haddad, Sérgio. A educação de pessoas jovens e adultas e a nova LDB. In: Brzezinski, Iria (Org.). $L D B$ interpretada: diversos olhares se entrecruzam. 7. ed. São Paulo: Cortez, 2002.p. 111-127.

. (Coord.). Novos caminhos em EJA: um estudo de ações do poder público em cidades de regiões metropolitanas brasileiras. São Paulo: Global, 2007.

.; Di Pierro, Maria. Aprendizagem de jovens e adultos: avaliação da década da educação para todos. São Paulo em Perspectiva, São Paulo: Fundação SEADE, v. 14, n. 1, 
p. 29-40,jan./mar.2000. Disponível em: <http://www.scielo.br/pdf/spp/v14n1/9800.pdf>. Acesso em: 30 mar. 2009.

MeLchior,José Carlos de Araújo. Financiamento da educação no Brasil numa perspectiva democrática. Cadernos de Pesquisa, São Paulo: Fundação Carlos Chagas, n. 34, p. 39-83, ago. 1980.

O financiamento da educaşão no Brasil. São Paulo: EPU, 1987. (Temas básicos de educação e ensino).

Oliveira, Dalila Andrade. Educação básica: gestão do trabalho e da pobreza. Petrópolis: Vozes, 2000.

Rummert, Sonia Maria; Ventura, Jaqueline Pereira. Políticas públicas para educação de jovens e adultos no Brasil: a permanente (re)construção da subalternidade - considerações sobre os Programas Brasil Alfabetização e Fazendo Escola.Educar, Curitiba: Editora UFPR, n. 29, p. 29-45, 2007.

Soares, Antonio Carlos Otoni. A instituição municipal no Brasil. São Paulo: Revista dos Tribunais, 1986.

Souza, Marcelo Medeiros Coelho de. O analfabetismo no Brasil sob o enfoque demográfico. Brasilia: IPEA, 1999. (Texto para Discussão, n. 639).

\section{SOBRE A AUTORA}

Geruza Cristina Meirelles Volpe é doutora em educação pela Universidade Estadual de Campinas (UNICAMP). Professora adjunta da Universidade Federal de Juiz de Fora (UFJF).

E-mail:profgeruza@bol.com.br 


\section{GERUZA CRISTINA MEIRELLES VOLPE}

O financiamento da educação de jovens e adultos em municípios mineiros no período de 1996 a 2006: até quando migalhas?

O presente texto problematiza o financiamento da educação de jovens e adultos (EJA) como direito, no interregno 1996 a 2006. Nele, focaliza-se o estudo empírico de Minas Gerais e de uma amostra de 24 municípios mineiros, perscrutada nas condições de oferta de sua rede municipal de ensino, na sua capacidade financeira e no seu gasto público em educação (de jovens e adultos). Compreende-se que o objeto investigado relaciona-se às diretrizes de: a) descentralização do financiamento e dos serviços educacionais, vinculada à questão federativa, à divisão de responsabilidades dos entes federados e à municipalização via política de fundos para seu financiamento; b) focalização, no fundamental regular, bem como dos beneficiários dos programas (os mais jovens e pobres); e c) privatização, traduzida em parcerias e apelo ao espírito voluntarioso da sociedade civil. Concluise que o financiamento da EJA é dimensão nevrálgica ainda não concretizada na democratização do Estado brasileiro.

Palavras-chave: educação de jovens e adultos; financiamento; políticas públicas; direito; municipalidades. 


\section{The education funding for youth and adult education in municipalities of Minas Gerais state from 1996 to 2006: until when only crumbs?}

This paper discusses the funding of the education of young people and adults as a fundamental right, from 1996 to 2006. It focuses on the empirical study of Minas Gerais State and that of a sample of 24 municipalities, their availability of municipal schools, funding capacity and public spending on the education of young people and adults. The study object relates to the guidelines for: a) the decentralization of educational funding and services, attached to the federative issue, to the division of responsibilities of subnational governments and to the municipalization of education through fund policy; b) focus on regular primary education, as well as on its beneficiaries (the younger and the poorer); and c) privatization, expressed in the form of partnerships as well as the request to the voluntary spirit of civil society. We conclude that the funding for the Education of Young People and Adults is a dimension of the democratization of Brazil that has not been implemented.

Keywords: education of young people and adults; education funding; public policy; law; municipalities.

\section{El financiamiento de la educación de jóvenes y adultos en municipios de Minas Gerais en el periodo de 1996 a 2006: ¿hasta cuándo seguiremos con las migajas?}

El texto discute el financiamiento de la educación de jóvenes y adultos (EJA) como un derecho, en el periodo de 1996 a 2006. La discusión se centra en un estudio empirico sobre el Estado de Minas Gerais y de una muestra de 24 municipios, examinada cuidadosamente en las condiciones de oferta de su red municipal de escuelas, en su capacidad financiera y en su gasto público en educación (de jóvenes y adultos). El objeto de estudio está relacionado con las directrices: a) descentralización del financiamiento y de los servicios, vinculada a la organización federativa, a la asignación de competencias y a la municipalización de la Educación vía politica de Fondos, b) centralización en la primaria regular así como en los beneficiarios (los más jóvenes y pobres), y c) privatización, que se expresa en las asociaciones, y en la convocatoria al espiritu voluntario de la sociedad civil. Se concluye que el financiamiento de la EJA es una dimensión central todavía no realizada de la democratización de Brasil.

Palabras clave: educación de jóvenes y adultos; financiamiento; políticas públicas; derecho; municipios. 